Eduvest - Journal of Universal Studies

Volume 1 Number 12, December 2021

p- ISSN 2775-3735 e-ISSN 2775-3727

\title{
INSURANCE PERSPECTIVE OF YUSUF QARDHAWI AND ABDUL WAHAB KHALAF
}

\author{
Ainul Mardhiah, Afrizal
}

IAI Syekh Maulana Qori Bangko, Indonesia

E-mail: ainulmardhiah1802@gmail.com, afrizalyet@gmail.com

\begin{tabular}{|c|c|}
\hline ARTICLE INFO & ABSTRACT \\
\hline $\begin{array}{l}\text { Received: } \\
\text { November, } 26^{\text {th }} \\
2021 \\
\text { Revised: } \\
\text { December, } 17^{\text {th }} \\
2021 \\
\text { Approved: } \\
\text { December, 19th } \\
2021\end{array}$ & $\begin{array}{l}\text { Insurance that has just emerged at this contemporary stage, its } \\
\text { quality causes mixed understanding among researchers. There } \\
\text { are several researchers who prohibit insurance, including Yusuf } \\
\text { al-Qardawi who blocks existing insurance, especially life } \\
\text { insurance. Yusuf al-Qardawi forbade insurance on the grounds } \\
\text { that according to him insurance is far from the idea of } \\
\text { exchange and solidarity with the association. Whereas in life } \\
\text { insurance, basically it is very possible to say that it is a broken } \\
\text { understanding. The explanation is because between the two } \\
\text { meetings there is a common desire and currently realizes that } \\
\text { the strengths of each are not solid. Insurance in Yusuf al- } \\
\text { Qardawi's view is that Islam does not recognize the current } \\
\text { type of insurance with every implementation, it does not mean } \\
\text { that Islam is against insurance as a whole, not in any way, what } \\
\text { Islam opposes is part of its implementation practice. According } \\
\text { to Abdul Wahaf Khalaf, insurance takes any form and can } \\
\text { benefit the local community as long as there is no usury, the } \\
\text { law is halal or allowed in Islamic teachings. }\end{array}$ \\
\hline KEYWORDS & Insurance, Yusuf Qardhawi, Abdul Wahab Khalaf \\
\hline cc) (i) (?) & $\begin{array}{l}\text { This work is licensed under a Creative Comn } \\
\text { Attribution-ShareAlike } 4.0 \text { International }\end{array}$ \\
\hline
\end{tabular}

\section{INTRODUCTION}

Islam is a comprehensive and comprehensive religion, and from all aspects. The aspect of human relationship with Allah SWT is the most important aspect in life because Allah created humans for none other than worship (Dawn, 1995). There is also an aspect of human relations with fellow humans, from this aspect we cannot live alone, we need other people. Aspects of human relationships with other creatures (Bruce, 2006). Humans

Ainul Mardhiah, Afrizal (2021). Insurance Perspective of Yusuf

Qardhawi and Abdul Wahab Khalaf. Journal Eduvest. 1(12): 1418-

1427

How to cite:

E-ISSN:

Published by:

https://greenpublisher.id/ 


\section{Ainul Mardhiah, Afrizal}

were created by Allah SWT as the most perfect creature among other creatures. One of the differences is that humans are creatures who have a mind that can be used for worship and can also be used to determine what is good and what is not. Many privileges are given by Allah SWT to humans, it's just that humans are not aware of and even grateful for what Allah has given to them. Humans also do not escape from dependence on others for survival (Musilova, Mulcahy, Kuijk, McLoughlin, \& Bowie, 2019). In this modern era, there have been many changes in the acquisition of models of human behavior, both in the muammalah and social fields. In the field of muamalah, the shift in the pattern of agriculture to industry has resulted in the migration of rural residents to cities.

The model change will not only bring benefits, but many problems will arise. Among them are egoism, materialism and declining morality, which in the end raises concerns among the public about the security problem of every resident, both in the city and in the village (Muncy \& Eastman, 1998). But every human being has luck in his life. There is a concept of luck in Islam, in this case it has three dimensions of time, namely profit in the short term, profit in the medium term and in the long term. Insurance in the early stages is a form of group that aims to help ease the financial burden of humans in order to avoid economic difficulties, both education, health and other problems based on the concept of helping in goodness and piety and providing good protection based on ukhuwah Islamiyah (Sula \& Hill, 2019).

Insurance is a social protection system that guarantees the benefit of the community which is arranged very neatly based on an agreement to help each other in a group. The purpose of insurance is to reduce the risk or loss for policyholders who are open to the possibility of death, injury due to accidents, large trade and corporate losses and others that may be faced (Sadgrove, 2016).

Insurance according to the Law of the Republic of Indonesia Number 2 of 1992 is an agreement between two or more parties, whereby the insurer binds himself with the insured, by receiving insurance premiums to provide compensation to the insured due to loss, damage, or loss of expected profits, or legal liability to third parties that may be suffered by the insured, arising from an uncertain event or to provide payments based on the death or life of the insured person (Susyanti, 2016).

In Islamic circles, insurance is considered un-Islamic. People who have insurance are the same as people who deny His mercy because only Allah SWT determines everything and determines the sustenance of His servants. People who involve themselves in this insurance is one of the efforts to face the future of old age (Gorman, 2017). However, because the issue of insurance is not explicitly explained in the texts, then the problem is seen as a matter of ijtihad, namely differences of opinion that are difficult to avoid and these differences of opinion must also be respected (Hasan, 2014).

However, insurance that has just emerged in this contemporary phase, its presence creates a difference in understanding among scholars (Nafiu, 2012). There are several scholars who forbid insurance, including Sheikh Yusuf al-Qardawi who forbids existing insurance, especially life insurance (Ahmad, Khan, Patel, Shehbaz, \& Sharofiddin, 2021). He forbade insurance because he thought that insurance was far from trade and solidarity with associations (Seyed Mohamed, 2016). Whereas in life insurance, at least it can be said as a broken contract (Cummins, Smith, Vance, \& Vanderhel, 2013). The reason is because between the two parties there is a common will and already know each other's advantages are not strong. Abdul Wahab Khalaf is of the opinion that any form of insurance is a cooperative that is beneficial to the community as long as there is no usury, the law is halal.

To provide a deeper understanding, in this article the author will discuss the basic differences between conventional and sharia insurance, insurance in Yusuf Qardawi's 
perspective and insurance in Abdul Wahab Khalaf's perspective.

\section{RESEARCH METHOD}

This research is a type of literature study research, this research only takes from published documents such as books, journals and others. The research method used is normative research method or legal research literature. The normative approach is used with the aim of reviewing and analyzing library materials or supporting information identified with research materials as legal essential materials, relating to research materials in the form of primary legal materials, secondary legal materials, and tertiary legal materials (Soekanto \& Sulistyowati, 2013)

The approach taken is based on the main source, examining theoretical matters relating to legal conceptions, legal principles, legal views and doctrines, statutory regulations and a whole series of laws using additional information, including: principles, rules, norms and legal rules contained in laws and regulations, legal books, journals and legal articles, and various archives that are expressly identified with research. This study will explain in an explanatory manner with the aim of describing in greater depth about insurance from the point of view of Yusuf al-Qardhawi and Abdul Wahab Khalaf.

\section{RESULT AND DISCUSSION}

\section{Fundamental Differences between Conventional Insurance and Sharia Insurance}

Conventional insurance or coverage is an agreement in which an insurer binds himself to an insured person, by obtaining a premium, to provide compensation to the insured due to a loss, damage or loss of expected benefits that may be experienced due to an uncertain event. Insurance is an agreement transaction between two parties, one party is obliged to pay contributions or commitments and the other party is obliged to provide full guarantees to the contributors or commitments if something happens to the first party in accordance with the agreement made. Insurance is an agreement related to coverage or guarantee for certain risks or misfortunes.

Meanwhile, sharia insurance is an effort to secure and mutually beneficial between various individuals or groups of people or parties through investments in the form of assets and/or tabarru providing a pattern of returns to face certain risks through contracts that are in accordance with sharia (Susyanti, 2016). Sharia insurance is an Islamic-based financial framework that is general in nature and applies to all beliefs and groups of people.

The sources of sharia insurance law are the Qur'an, sunnah, ijma', fatwas of friends, maslahah mursalah, qiyas, isttihsan, urf/traditions, and DSN-MUI fatwas. Thus, sharia insurance is always consistent and in accordance with sharia standards. In determining the principles, practices, and operations of sharia insurance, the limit that is consistently used as a reference is Islamic sharia which is sourced from the Qur'an, hadith, and Islamic jurisprudence. 
Conventional insurance law sources have legal sources based on the human mind, philosophy and culture, while the modus operandi is based on positive law. Therefore, if they do not have a legitimate source, they will usually enter into transactions that lack certainty and clarity. Similar to the case in the ma'qud 'alaih contract (something that is contracted) there is a sharia deformity because it is not clear (gharar) how much the insurance member will pay which includes how much something will be obtained (yes or no, big or small), unknown how long an insurance member has to pay premiums.

\section{Yusuf Qardhawi's Perspective Insurance}

Insurance as one of the financial institutions engaged in insurance is an advanced organization created by the western world which was brought into the world together with the spirit of enlightenment (reinaissannce). These organizations together with financial institutions banks were the main drivers of the economy in the past and continue to this day. The basis of the operational spirit of modern insurance is that it is oriented towards the capitalist system which basically only plays a role in raising capital for individual or organizational needs, and lacks or no roots to develop the economy at a more complete level.

Insurance issues in the perspective of Islamic teachings, including the issue of ijtihadiyah, the law needs to be studied as deeply as possible with reasons not explicitly explained by the Qur'an and Sunnah. Mujtahid imams such as Abu Hanifah, Imam Malik, Imam Shafi'i, Imam Ahmad bin Hanbal and the mujtahids who were with him did not give fatwas regarding insurance because at that time insurance was not known.

Islamic jurists are fully aware that the legal status of insurance has never been established by Islamic legal thinkers in the past. The possibility of insurance began to emerge when there was an assimilation of Islamic culture with European culture. However, if examined in depth, it will be known that insurance has benefits in it so that Islamic law scholars take insurance management based on sharia principles.

In line with the growth of Islamic law, the socio-cultural community towards the development of Islamic law is very strong, as can be seen from the results of the ijtihad of the madhhab imams. The impact of adat in legal life is something that should not be worried about. This is on the grounds that, the law that starts from adat in principle contains a dynamic process of rejecting the bad and accepting the good in accordance with the objective needs of the community. The issue becomes real when the growth of a community habit is absolutely against the law. Islamic law requires the traditions of the general public as a source of law as long as these customs do not conflict with the texts of the Qur'an or Sunnah. The discussion of insurance in the Islamic concentrate space only emerged at the time of the birth of contemporary researchers or scholars. One of them is Yusuf Qardhawi.

From the previous conversation, it is clear the contrast between conventional insurance and Islamic insurance, where in conventional insurance companies, speculation depends on interest. The company is also allowed to decide on its speculation, having the place with the benefits of the speculation belongs to the company. By looking at the previous discussion, the author tries to relate it to the insurance mentioned by Yusuf Qardhawi.

Yusuf Qardhawi wrote that Islam does not recognize the current type of insurance with every practice, that does not mean Islam is against insurance as a whole, not at all, what Islam is against are some principles and methods. Regarding the assumption that there are alternative ways that are not contrary to Islamic law, Islam positively relates it well. Social security in Islam actually exists whether it is carried out by the community with the concept of takaful (helping each other) or carried out by the government and 
baitul mal. Baitul mal is general insurance for all individuals who are under the teachings of Islam.

In his book, Yusuf Qardhawi describes that: In accident insurance the client or customer pays a certain amount of cash (premiums) in a year if something insured is safe, the company takes all the premiums, and if the client or customer is struck by a disaster the company will compensate according to the agreement that has been agreed upon. made. This kind of practice, according to him, is very far from the commercial nature and far from the meaning of isytirak tadhammun. Whereas in life insurance, if the client or customer agrees on a dependent money of Rp. 200 million, then when death befalls the client or customer will receive compensation of Rp. 200 million, even though he only paid the first premium when death befell him.

The insurance referred to by Yusuf Qardhawi is conventional insurance. We can also see this from the historical setting when he gave a fatwa. This fatwa was issued around the '60s, in accordance with the publication of his book, especially al-Halal wa alHaram fi al-Islam. It can also be said that in those years there were no insurance companies based on sharia (takaful) because takaful insurance developed in the 1970s in several Islamic countries or countries with a majority Muslim population.

According to Yusuf Qardhawi, the agreement in insurance is a broken agreement, if the client or customer does not comply with company rules and does not have the ability to pay the next premium, the premium paid will be lost or reduced. The reason that both parties let each other and understand each other is also unacceptable. Because in usury and gambling both parties also accept or are willing (Qardhawi, 2010).

Yusuf Qardhawi clearly forbids conventional insurance, but he basically does not reject the idea of insurance. Because according to him in Islamic law there is a guarantee for every individual to get help when a disaster strikes. For example, guarantees for people who are in debt (gharim) in the distribution of zakat. In some interpretations of the Salaf scholars it is stated that including gharim are people whose houses are burned, people whose merchandise is washed away by floods, or the like (Qardhawi, 2010)

According to Yusuf Qardhawi, insurance is absolutely unacceptable if the requirements are as follows:

a. All insurance participants do not pay cash with the aim of tabarru', even this purpose happens to them in any way.

b. Insurance organizations manage their money through usury, while every Muslim does not advocate syirkah by means of usury. And this has been mutually agreed upon by both those tightening up as well as by those moderating the issue.

c. The insurance member will take the amount of money that has been deposited and an additional amount from the company when the specified time has expired.

d. Anyone who wants to withdraw his money, then he will experience a very large loss. While this decline is really strange from the perspective of Islamic law.

There is usury in insurance. In this situation the author sees that with the reasons described above by Yusuf Qardawi, we already know that usury is unlawful for Muslims. So in order for transactions to occur that are in accordance with and desired by Islamic sharia, they must eliminate usury, by investing funds in various businesses that are in accordance with Islamic teachings.

Yusuf Qardhawi said in his book "Halal and Haram in Islam" that accident insurance should be adapted to Islamic teachings based on Islamic law sources, namely in the form of a rewarded contribution, for example an insurance member pays money to a company on the condition that he will be rewarded a sum of money because he is hit by an accident. disaster, as an aid to relieve his suffering at that time. This form of insurance is justified in the view of some of the madhhab priests. If insurance can be adjusted like 


\section{Ainul Mardhiah, Afrizal}

that, and the company that runs it does not have an element of usury, then it is permissible in Islamic teachings. As for life insurance according to its current form as mentioned above, according to Yusuf Qardawi's opinion, it is completely far from the teachings of Islamic law (Qardhawi, 2010).

To make insurance based on Islamic law, according to Yusuf Qardhawi, accident insurance transactions can be changed in an Islamic form in accordance with Islamic law, close transactions are in the form of donations to get compensation, concretely a customer deposits a number of funds with the aim that he gets compensation if he is hit by an accident. . If the insurance is changed to this form and the company that manages it is also free from usury, then the law becomes permissible. As for life insurance, according to him, this insurance is really far from a transaction that is justified by Islam.

Islam cannot accept conventional insurance with all the practices that have been applied, so this does not mean Islam is against the idea of insurance. This is not the case at all, what Islam opposes are several principles and methods. As for if there are other ways that do not conflict with the teachings of Islamic law, then Islam will certainly welcome it (Fauziyah, 2010).

Islamic law has guaranteed its ummah and those who live under the auspices of the Islamic government in its own way, in all its norms and directives. sometimes the guarantee comes from the solidarity of the community itself, and sometimes through the government and baitul mal institutions.

According to Yusuf Qardhawi, insurance is not allowed under Islamic law. Where the contract or contract in insurance is different from a contract or contract in a trade transaction and cooperation. The main reason for the prohibition of insurance is because of usury. First, with insurance, the customer receives the entire premium paid with some additions from the insurance provider (if the specified period has passed). Second, insurance companies invest in various ribawi businesses. In preparing the insurance law, Yusuf Qardhawi used the basis of the Qur'an and Hadith. The rejection of usury has been clarified in the Qur'an Surah Albaqarah verse 275 as follows:

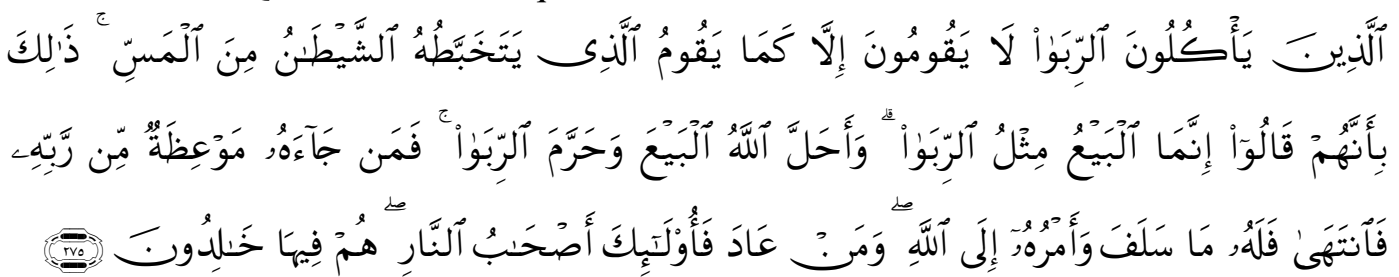

Those who eat (take) usury cannot stand but like the standing of a person who is possessed by Satan because of (pressure) madness. Their condition is like that, is because they say (opinion), Verily buying and selling is the same as usury, even though Allah has justified buying and selling and forbidden usury. those who have reached him a prohibition from his Lord, then continue to stop (from taking usury), then for him what he had taken first (before the prohibition came); and affairs (up to) to Allah. people who return (take usury), then that person is the inhabitants of hell; they stay in it. (QS. Albaqarah [2].275).

As seen from the explanation above, Yusuf Qardhawi also has a moderate view. He does not completely forbid insurance, but he also does not accept the situation as it is, meaning he will not justify a problem just because society requires it, even though we know it violates Islamic law. In fact, he tried to strike a balance by adjusting insurance transactions with Islamic law. In choosing the middle way, Beliu also stated the basis, 
that in Islamic law, every individual is guaranteed to receive assistance if a disaster strikes.

The insurance system from Abdus Sami' Almisri's perspective that the current insurance system relies on the demonstration of usury pioneered by the Jews so far. It was the Jews who ordered us to insure all things, so that even people's lives had to be insured or guaranteed. In addition, the Jews also make various risky or problematic issues in this insurance.

According to the fuqoha, the operational system of insurance companies contains elements of usury, fadl and nasiah from three points of view, namely:

a. An insurance contract is an agreement between an insurance company and an individual that is guaranteed to pay a certain amount of cash (premium) in lieu of another amount of money that will be paid by the company when an event occurs. Therefore, this is a transaction and the acquisition of money with money, if both are the same amount, it is called usury nasa and if more is given, it is called usury fadl.

b. In life insurance, if the participant is alive, the amount of money he has paid is returned plus a certain amount, then the addition of the money given is usury.

c. Most practices carried out by insurance companies are based on usury, such as funds invested in a company whose profits contain interest, borrowing money guaranteed by an insurance policy with interest, if premium payments are late, they will be fined money (Hasan, 2014).

It can be observed that Yusuf Qardhawi prohibits insurance in its entirety in all its forms and forms considering that insurance is basically the same as gambling. is paid, then the premiums that have been paid by the policyholder are played in the practice of usury (considering the money is credited and the income paid or interest is paid), Insurance includes a sharfi contract, which means buying and selling or buying and selling of money without money. The life and death of people are made into business objects, which means that they precede the destiny of Allah Almighty.

\section{Insurance Perspective Abdul Wahab Khalaf}

Abdul Wahab Khalaf is one of the scholars who allow insurance. According to Abdul Wahaf Khalaf, insurance, regardless of its form, is a cooperative that benefits the community as long as there is no usury, the law is halal or allowed in Islam. There are several reasons put forward by Abdul Wahaf Khalaf, namely:

a. There is no text of the Qur'an and Hadith that explicitly and clearly denies the practice of insurance

b. There is an agreement and willingness in insurance between the premium holder and the insurance agent

c. Insurance benefits both players

d. Insurance contains the general benefit, because the premiums collected can be used as resources for development activities

e. Insurance combines a mudarabah contract or contract between the premium holder and the insurance agent

f. Insurance includes syirkah at-ta'awujiyah, which is a joint business that depends on or is based on the principle of mutual help and the funds or assets collected are tabarru assets or funds.

For these reasons, insurance is considered to bring benefits to the participants and the insurance company at the same time. Practices or actions that can bring benefit to many people are justified by Islamic teachings.

There is no contradiction that insurance is an idea and a system based on the concept of providing help and protection. Both concepts are matters that are in 


\section{Ainul Mardhiah, Afrizal}

accordance with the aims and purposes of the Shari'a. Even though the Shari'a makes help an obligation, the method and approach to giving help is explained by Islam so that it does not become a matter of doubt and deception occurs against humans. Islamic Shari'a does not only determine the goals and intentions to provide help but also determines the correct way to achieve that good goal.

The conflicting assessments of the scholars who legitimize and hinder the current insurance system depend on contrasts in understanding and various perspectives on the guidelines for insurance contracts themselves. The group that legitimizes by focusing on the goals of the insurance system, especially prudence, goodness and guarantees for the welfare of life and property. Meanwhile, the group that prohibits or forbids underlines the unfavorable components in the insurance system such as usury.

Afzal Rahman said that this insurance issue should be considered without taking sides with either party where he also stated that Islamic Shari'a has established general rules that determine the details of business agreements or economic alliances, as long as the trade contract does not exceed the boundaries, it is decided that it is halal. and legal. Apart from the fact that it is legal and legal, there are haram components such as usury, gharar, maisir, therefore an insurance system must be made in accordance with Islamic standards (Hasan, 2014).

In addition to Abdul Wahab Khalaf, Sheikh Ali Al-Kafif said the same thing about insurance, namely:

a. Insurance is a new agreement that is not in certain texts. Therefore insurance is allowed

b. Insurance is an agreement that leads to good and there is no bad behind it. If there is good, then Allah's law is born that allows it

c. It has become an indispensable habit for the good of society at large or for individuals. Customs are the source of Shari'ah law

d. It is also a necessity that is close to an emergency that must exist and there is no subhat element in it

e. In the insurance scheme, there is a responsibility that is considered to be greater than the obligation to keep promises according to the Maliki school, it must be carried out (Hasan, 2014).

Social insurance, such as health insurance and accident insurance, is caused by work. The state does this to everyone who pays the premium determined for that purpose, the state also fulfills the deficiency contained in the difference between the money that has been collected and the money that has paid the loss. So this insurance leads to the general benefit of a social nature. Therefore, this insurance is justified by Islam. Abdul Wahab Khalaf allows insurance because it analogizes or confirms insurance to a pension system such as taspen.

Abdul Wahaf Khalaf allows all forms of insurance in practice today on the grounds that there are no texts of the Qur'an and Hadith that clearly and unequivocally prohibit insurance activities and there are also no texts that explicitly command this insurance, in insurance there is an agreement and willingness between both parties, insurance does not harm both parties, but benefits both parties. Because insurance contains public interest, because the premiums collected can be invested in development activities, insurance includes a mudarabah contract between the policy holder and the insurance company, insurance includes syirkah at-ta'awujiyah.

\section{CONCLUSION}

Insurance that has just emerged at this contemporary stage, its quality causes mixed 
understanding among researchers. There are several researchers who prohibit insurance, including Yusuf al-Qardawi who blocks existing insurance, especially life insurance. This research is a type of literature study research, this research only takes from published documents such as books, journals and others. The research method used is normative research method or legal research literature. The conclusion of this study is that Abdul Wahaf Khalaf allows all insurance practically today considering the fact that there is no text of the Qur'an and Hadith that explicitly prohibits insurance activities, in insurance there is an agreement and willingness between both parties, insurance benefits both parties. , insurance contains the public interest, because the premiums collected can be invested in development activities, insurance includes a mudarabah contract between the policy holder and the insurance company, insurance includes syirkah at-ta'awujiyah, which is a joint effort based on the principle of mutual help and the funds collected is a tabarru' fund, insurance protects many individuals from property, wealth, and personal accidents, insurance activities are carried out for the public benefit and common interest.

\section{REFERENCES}

Ahmad, Ghafoorzai Shaiq, Khan, Mohammad Bilal, Patel, Ibadurrehman, Shehbaz, Damkar Mohammed, \& Sharofiddin, Ashurov. (2021). Developing The Hybrid Model (Waqf \& Zakat) For Improving The Zakat Recipients' Healthcare In Selangor. Journal of Islamic Finance, 10, 67-75.

Bruce, Kyle. (2006). Henry S. Dennison, Elton Mayo, and human relations historiography. Management \& Organizational History, 1(2), 177-199.

Cummins, J. David, Smith, Barry D., Vance, R. Neil, \& Vanderhel, J. L. (2013). Risk classification in life insurance (Vol. 1). Springer Science \& Business Media.

Dawn, Marva J. (1995). Reaching out without dumbing down: A theology of worship for this urgent time. Wm. B. Eerdmans Publishing.

Fauziyah, Ririn. (2010). Pemikiran Yusuf Qardhawi mengenai zakat saham dan obligasi. Universitas Islam Negeri Maulana Malik Ibrahim.

Gorman, Mark. (2017). Development and the rights of older people. In The ageing and development report (pp. 3-21). Routledge.

Hasan, Mudrika Alamsyah. (2014). Pengaruh Kepemilikan Manajerial, Free Cash Flow dan Ukuran Perusahaan Terhadap Kebijakan Utang (Studi Pada Perusahaanperusahaan Industri Dasar dan Kimia yang Terdaftar di BEI). Jurnal Akuntansi (Media Riset Akuntansi \& Keuangan), 3(1), 90-100.

Muncy, James A., \& Eastman, Jacqueline K. (1998). Materialism and consumer ethics: An exploratory study. Journal of Business Ethics, 17(2), 137-145.

Musilova, Jana, Mulcahy, Michelle E., Kuijk, Marieke M., McLoughlin, Rachel M., \& Bowie, Andrew G. (2019). Toll-like receptor 2-dependent endosomal signaling by Staphylococcus aureus in monocytes induces type I interferon and promotes intracellular survival. Journal of Biological Chemistry, 294(45), 17031-17042.

Nafiu, Olaitan Sarafadeen. (2012). A Framework of Islamic Economics With Reference to Islamic Taxation and Allowable Expenditures. IIUM Law Journal, 20(2).

Qardhawi, Yusuf. (2010). Fiqih jihad: sebuah karya monumental terlengkap tentang jihad menurut al-Quran dan Sunnah. PT Mizan Publika.

Sadgrove, Kit. (2016). The complete guide to business risk management. Routledge.

Seyed Mohamed, Mohamed Mazahir. (2016). Operation of Islamic insurance in Sri Lanka: Developments and challenges/Seyed Mohamed Mohamed Mazahir. University of Malaya. 


\section{Ainul Mardhiah, Afrizal}

Soekanto, Soerjono, \& Sulistyowati, Budi. (2013). Sosiologi Suatu Pengantar (Edisi Revisi). Jakarta: Raja Grafindo Persada.

Sula, Chris Alen, \& Hill, Heather V. (2019). The early history of digital humanities: An analysis of Computers and the Humanities (1966-2004) and Literary and Linguistic Computing (1986-2004). Digital Scholarship in the Humanities, 34(Supplement_1), i190-i206.

Susyanti, Jeni. (2016). Pengelolaan Lembaga Keuangan Syariah. Malang: Empat Dua. 